\title{
Pengembangan Panduan Bimbingan Keterampilan Kerjasama Berbasis Permainan Tradisional Balbudih untuk Siswa SMP
}

\author{
Siti Hartinah ${ }^{1}$, Agus Dwi Setyawan ${ }^{2}$ \\ ${ }^{1}$ Mahasiswa Program Studi Magister Bimbingan dan Konseling, Universitas negeri Malang \\ ${ }^{2}$ Guru PJOK, SDN Aenganyar I Giligenting, Sumenep Madura \\ e-mail: alsasetyawam@gmail.com
}

\begin{abstract}
The objectives in this study consist of 2 specific objectives, namely (1) general objectives, namely to produce guidance guidelines on cooperation skills based on Balbudih Traditional Games for junior bigh school students. And, (2) specific objectives namely (a) to produce guidance on cooperation skills that meet acceptability carried out through expert testing and prospective user testing, (b) to produce guidance guidelines based on traditional Balbudih games that are effective for enhancing cooperative skills. This research is a research development of the Borg and Gall model that examines the development of guidelines for cooperation skills based on the Traditional Balbudih Games for junior high school students. Small group trial subjects were conducted on 12 junior high school students. This study uses data collection techniques namely observation, interviews and questionnaires. The results of the study show that: (1) the results of developing guidelines for the guidance of cooperation skills based on the Traditional Balbudih Games for junior high school students have met the acceptability criteria which are carried out through expert tests and prospective user tests. (2) Producing guidance guides based on traditional Balbudih games which are effective for improving the cooperation skills of junior high school students.
\end{abstract}

Keywords: Balbudih Traditional Game, Cooperation Skills

\begin{abstract}
Abstrak. Tujuan dalam penelitian ini terdiri atas 2 tujuan spesifik, yaitu (1) tujuan umum, yaitu untuk menghasilkan panduan bimbingan ketrampilan kerjasama berbasis Permainan Tradisional Balbudih untuk siswa SMP. Dan, (2) tujuan khusus yaitu (a) untuk menghasilkan panduan bimbingan ketrampilan kerjasama yang memenuhi akseptabilitas yang dilakukan melalui uji ahli dan uji calon pengguna, (b) untuk menghasilkan panduan bimbingan berbasis permainan tradisional Balbudih yang efektif untuk meningkatkan keterampilan kerjasama. Penelitian ini merupakan penelitian pengembangan model Borg and Gall yang menelaah pengembangan panduan bimbingan ketrampilan kerjasama berbasis Permainan Tradisional Balbudih untuk siswa SMP. Subjek uji coba kelompok kecil dilakukan kepada siswa SMP sebanyak 12 siswa. Penelitian ini menggunakan teknik pengumpulan data yaitu observasi, wawancara dan angket. Hasil penelitian menunjukkan bahwa: (1) menghasilkan mengembangkan panduan bimbingan ketrampilan kerjasama berbasis Permainan Tradisional Balbudih untuk siswa SMP telah memenuhi kriteria akseptabilitas yang dilakukan melalui uji ahli dan uji calon pengguna. (2) Menghasilkan panduan bimbingan berbasis permainan tradisional Balbudih yang efektif untuk meningkatkan keterampilan kerjasama siswa SMP.
\end{abstract}

Kata Kunci: Permainan Tradisional Balbudih, Keterampilan Kerjasama 


\section{PENDAHULUAN}

Perkembangan teknologi yang terjadi akibat adanya perkembangan jaman terjadi dengan sangat pesat. Seiring dengan hal tersebut, penggunaan gadget pun semakin meningkat. Demam gadget ini tidak hanya melanda orang dewasa, namun kini tidak sedikit anak-anak yang sudah mulai mengenal bahkan sangat mahir mengoperasikan gadget. Seperti pisau yang memiliki dua sisi, keberadaan gadget membawa dampak positif dan juga dampak negatif. Dokter anak asal Amerika Serikat, Cris Rowan (dalam Metrotvnews.com, no.36) menegaskan bahwa selayaknya harus ada pelarangan dalam penggunaan gadget pada anak usia kurang dari 12 tahun. Hal ini dikarenakan dari beberapa penelitian yang dilakukan bahwa gadget memberikan dampak negatif daripada dampak positif dalam kehidupan anak-anak. Psikolog anak, Anna Surti Ariani (dalam Metrotvnews.com) mengemukakan bahwa jika seorang anak terlalu sering menggunakan gadget, maka akan berdampak pada menurunnya wawasan dan kecerdasan anak.

Sebuah kasus akibat kecanduan gadget terjadi di Bondowoso, dimana ada dua remaja yang kecanduan gadget. Hasil diagnosa kejiwaan menyebutkan bahwa kedua pelajar tersebut mengalami kecanduan dalam kondisi akut. Mereka sering sekali marah-marah sampai membanting benda disekitarnya, yang parah mereka menyakiti diri sendiri jika gadget yang sedang mereka gunakan, diambil oleh orang lain (Ali, 2018).

Berdasarkan hasil penelitian yang dilakukan oleh Febriana (2017), Anak-anak dengan kecenderungan kecanduan gadget berpengaruh pada pergaulan sosialnya terhadap lingkungan sosialnya. Anak yang kecanduan gadget akan merasa asing dengan lingkungan di sekitarnya karena kurang peka serta memiliki kecenderungan untuk tidak peduli terhadap lingkungannya.

Bimbingan dan konseling sebagai bagian integral dari kegiatan pendidikan yang memiliki fungsi untuk memandirikan siswa sehingga dapat memenuhi tugas perkembangan dengan lebih baik. Berdasarkan Permendiknas no. 27 tahun 2008 disebutkan bahwa keberadaan konselor dalam sistem pendidikan nasional dinyatakan sebagai kualifikasi pendidik yang sejajar dengan kualifikasi guru, dosen, pamong belajar, tutor, widyaiswara, fasilitator dan instruktur. Konteks tugas konselor berada pada wilayah pelayanan untuk mengembangkan potensi dan memandirikan konseli. Namun, kenyataan di lapangan, sebagian besar sekolah masih kekurangan tenaga konselor. Sehingga pelayanan terhadap masalah peserta didik tidak dapat diatasi dengan maksimal dan sesegera mungkin.

Salah satu alternatif yang dapat untuk mengurangi ketergantungan gadget adalah dengan menggunakan sarana permainan sebagai medianya. Permainan sebagai sarana utama yang digunakan sebagai metode pelatihan yang memang selayaknya disesuaikan dengan tahap-tahap 
perkembangan anak. Dalam hal ini, anak-anak yang dimaksudkan adalah siswa SMP kelas VII dimana siswa SMP kelas VII tersebut berada dalam masa perkembangan anak-anak yang dalam masa ini tahap perkembangannya disebut juga dengan masa bermain (Hurlock, 1990). Sehingga kegiatan yang digunakan sebagai alternatif pengalihan kecanduan gadget merupakan kegiatan yang dekat dengan dunia anak yaitu dunia bermain.

Plato, Aristoteles dan Frobel (dalam Mayke, 2005) beranggapan bahwa bermain merupakan sebuah kegiatan yang memiliki nilai praktis, dimana bermain digunakan sebagai media untuk meningkatkan kemampuan dan keterampilan tertentu pada anak. Melalui kegiatan bermain, diharapkan anak-anak dapat memperoleh manfaat bagi peningkatan perkembangan fisik-motorik, kecerdasan dan sosial emosionalnya. Bermain dipilih sebagai salah satu alternatif dalam mengalihkan kecanduan gadget dikarenakan bermain berisi aktivitas yang menyenangkan dan bermain merupakan kebutuhan dasar bagi anak-anak sehingga anak-anak dapat melakukan proses belajar berbagai keterampilan dengan senang hati tanpa ada paksaan untuk mempelajarinya. Bermain memiliki banyak manfaat dalam proses pengembangan keterampilan anak sehingga anak-anak menjadi lebih siap dalam proses adaptasi dengan lingkungan sekitarnya.

Menurut Hurlock (1990) pola permainan yang bisa digunakan untuk mendukung perkembangan sosial pada anak yaitu pola permainan yang memiliki nuansa sosial dimana pola permainan yang digunakan berupa pola interaksi dengan teman sebayanya. Pola permainan yang bernuansa sosial tersebut bisa digunakan sebagai media dalam melatih keterampilan sosial anak yang kecanduan gadget. Dimana indikator anak-anak yang kecanduan gadget berupa kesulitan untuk beradaptasi dengan lingkungan sosialnya. Pola-pola permainan sosial seperti yang disebutkan diatas, banyak ditemukan dari berbagai permainan tradisional yang terdapat di Indonesia.

Bishop dan Curtiz (2005) mendefinisikan permainan tradisional sebagai jenis permainan yang diturunkan dari satu generasi ke generasi selanjutnya dinama permainan tersebut mengandung nilai-nilai positif. Permainan tradisional merupakan salah satu wujud kebudayaan sebagai sebuah aktivitas yang berupa aktivitas interaksi masyarakat suatu budaya. Kondisi ini menunjukkan bahwa berbagai jenis permainan tradisional yang dimiliki merupakan aset budaya yang harus dilestarikan keberadaannya. Permainan tradisional merupakan salah satu unsur kebudayaan yang memiliki pengaruh yang besar terhadap kehidupan masyarakatnya sebagaimana yang diungkapkan oleh Sukirman (2008), bahwa permainan tradisional anak memberikan pengaruh yang besar terhadap perkembangan kejiwaan, sifat, dan kehidupan sosial anak dikemudian hari. Menurut Sujarno (2010), permainan tradisional merupakan hasil budaya yang 
besar nilainya bagi anak dalam rangka berfantasi, berekreasi, berolah raga dan sebagai sarana untuk berlatih hidup sopan dan terampil dalam bermasyarakat.

Kehidupan masyarakat baik yang kompleks maupun sederhana memiliki nilai budaya yang dipakai sebagai pedoman dalam kehidupan yang penting dan bernilai. Kebudayaan sebagai karya manusia memiliki sistem nilai, menurut C. Kluckhon (dalam Siti Irene Astuti, 2012), sistem nilai budaya secara universal menyangkut lima masalah pokok kehidupan manusia, yaitu:

a. Masalah hakekat dan hidup manusia $(\mathrm{MH})$

b. Masalah hakekat dan karya manusia (MK)

c. Masalah hakekat dari kedudukan manusia dalam ruang waktu (MW)

d. Masalah hakekat hubungan manusia dengan alam sekitar (MA)

e. Masalah hakekat hubungan manusia dengan sesama (MM)

Oleh karena itu, agar sistem nilai budaya dapat menjadi landasan hidup masyarakat maka, anak sejak dini sudah harus diperkenalkan pada budaya masyarakatnya dan dikembangkan aspek sosialnya melalui perrmainan tradisional.

Salah satu ciri khas dalam permainan tradisional yaitu permainan ini kebanyakan dilakukan oleh dua orang atau lebih. Permainan tradisional biasanya berupa permainan tim atau kelompok yang dilakukan dengan cara tatap muka dan kompetisi antar kelompok. Dalam permainan tradisional ini, dimungkinkan munculnya suatu kondisi bagi anak untuk berinteraksi dengan teman sebayanya. Saat melakukan permainan tradisional, anak dituntut untuk berkumpul, mengenal dan berinteraksi dengan teman sepermainannya.

Dharmamulya (dalam Ariani, 1998) menyebutkan bahwa ada beberapa nilai yang terkandung dalam permainan tradisional yang dapat dtanamkan dalam diri anak diantaranya perasaan senang, bebas, berteman, demokratis, tanggung jawab, patuh dan saling membantu sesama. Berbagai nilai luhur yang terkandung dalam permainan tradisional menunjukkan bahwa permainan tradisional dapat digunakan sebagai media yang tepat untuk membentuk kepribadian anak (Araini, 1998).

Permainan tradisional balbudih merupakan permainan tradisional yang berasal dari Pulau Madura tepatnya di daerah Kabupaten Sumenep, Jawa Timur. Permainan tradisional Balbudib ini merupakan permainan asli dari daerah Sumenep. Kata Babudih adalah berasal dari bahasa Madura yang mempunyai dua kata, Bal artinya Bola, dan Budih artinya belakang, jadi Balbudih adalah permainan bola belakang.

Permainan Tradisional Bal Budi ini dilakukan oleh 18 orang yang terbagi dalam dua tim/kelompok. Masing-masing kelompok beranggotakan 9 (sembilan) orang. para pemain Bal 
Budi ini biasanya berusia 12 tahun sampai dewasa. Dalam permainan Bal Budi, para pemain dalam setiap kelompok terdiri dari berbagai jenjang usia, dari anak-anak, pemuda ataupun orang tua.

Alat yang digunakan dalam permainan Bal Budi ini berupa sebuah bola. Bola ini merupakan alat utama yang digunakan dalam permainan Bal Budi. Jenis bola yang digunakan tidak ada batasan spesifiknya. Beberapa jenis bola yang biasa digunakan seperti bola yang terbuat dari rumput yang kemudian diikat menjadi bundar, bola yang digunakan bisa juga terbuat dari pelepah pisang, daun kelapa, jerami atau gulungan baju yang diikat dan dibentuk bundar menyerupai sebuah bola. Dalam perjalanannya, bola yang digunakan dalam permainan Bal Budi ini adalah bola tenis. Hal ini dikarenakan ukuran bola tenis yang pas dengan ukuran tangan, praktis dan mudah didapatkan.

Alat lain yang digunakan dalam permainan tradisional Bal Budi ini yaitu sebuah lapangan. Lebar sebuah lapangan Bal Budi sebesar 3 (tiga) meter dan panjang lapangan tidak terbatas. Permainan tradisional balbudib ini mengajarkan nilai-nilai gotong royong, toleransi, dan tidak membedakan teman, dimana ketiga hal tersebut tercakup dalam keterampilan kerjasama. Salah satu nilai luhur yang sangat menonjol dalam permainan tradisional adalah keterampilan kerjasama.

Flynn berpandangan bahwa keterampilan bekerja sama merupakan keterampilan yang sangat diperlukan ketika memasuki dunia kerja (Flynn, 1995; Graham \& Graham, 1997). Davis \& Miller (1996) juga menyebutkan bahwa dengan bekerja secara kolaborasi, maka siswa akan menjadi lebih sukses sebagai bagian dari tim dan memiliki kinerja yang berkualitas. Johnson dan Johnson (1991) mengartika kerjasama sebagai bentuk bekerja bersama-sama untuk mencapai tujuan bersama. Berdasarkan hal tersebut, maka kerjasama dapat didefinisikan sebagai sekumpulan/kelompok orang-orang yang saling membantu dan saling bergantung satu sama lain dalam melakukan suatu kegiatan untuk mencapai tujuan tertentu.

Sebuah penelitian yang dilakukan oleh Elsje Teodora (2011) tentang kemampuan kerjasama yang dikembangkan melalui metode pembelajaran inkuiri pada siswa kelas VII SMP, terungkap bahwa siswa yang memiliki keterampilan kerjasama yang tinggi akan menunjukkan rata-rata nilai yang lebih tinggi dibandingkan dengan siswa yang memiliki keterampilan kerjasama yang rendah. Dari penelitian diatas, dapat disimpulkan bahwa keterampilan kerjasama memiliki pengaruh yang besar dalam keberhasilan kegiatan belajar. Keterampilan kerjasama mendorong siswa untuk lebih fleksibel dalam berinteraksi dengan teman sebayanya. Siswa yang memiliki keterampilan kerjasama yang baik akan mudah bergaul, mudah beradaptasi dengan lingkungan sekitarnya sehingga dapat diterima dengan baik oleh lingkungan. 
Tujuan dalam penelitian ini terdiri atas 2 tujuan spesifik, yaitu (1) tujuan umum, yaitu untuk menghasilkan panduan bimbingan ketrampilan kerjasama berbasis Permainan Tradisional Balbudih untuk siswa SMP. Dan, (2) tujuan khusus yaitu (a) untuk menghasilkan panduan bimbingan ketrampilan kerjasama yang memenuhi akseptabilitas yang dilakukan melalui uji ahli dan uji calon pengguna, (b) untuk menghasilkan panduan bimbingan berbasis permainan tradisional Balbudih yang efektif untuk meningkatkan keterampilan kerjasama.

\section{METODE}

Dalam penelitian ini pendekatan yang digunakan adalah "Penelitian Pengembangan" (Research and Development). Menurut Borg and Gall (2003) strategi research and development (R\&D) ini berupa siklus pengembangan yang terdiri dari 8 langkah pengembangan, diantaranya yaitu: (1) analisis kebutuhan; (2) observasi awal; (3) perencanaan pengembangan; (4) pengembangan produk awal; (5) uji lapangan awal (validasi ahli); (6) revisi I; (7) uji kelompok kecil; dan (8) revisi II.

Penelitian pengembangan ini dilakukan pada siswa SMP Negeri 1 Saronggi Kabupaten Sumenep. Dalam tahap uji ahli atau validasi ahli, peneliti mengujikan produk yang berupa panduan permainan tradisional Balbudih kepada dua ahli; yaitu ahli bimbingan dan konseling dan ahli media pendidikan.

Teknik pemilihan sampel yang dilakukan dengan cara purposive sampling atau sampel bertujuan. Jenis data yang diperoleh dalam pengembangan panduan bimbingan ketrampilan kerjasama berbasis permainan tradisional Balbudih ini berupa data kualitatif dan data kuantitatif.

Instrument pengumpulan data yang digunakan dalam penelitian ini adalah observasi dan wawancara yang digunakan untuk pengumpulan data awal, kemudian digunakan pula angket penilaian akseptabilitas yang diberikan kepada 2 orang ahli, serta angket respon dari siswa dan guru yang sebelumnya telah diberikan buku panduan permainan tradisional Balbudih.

\section{TEMUAN}

Berdasarkan hasil observasi awal melalui kegiatan pengamatan langsung di SMPN I Saronggi, Sumenep, Madura, terlihat bahwa di beberapa kelas selalu ada anak-anak yang menyendiri, diabaikan dan dihindari oleh teman-temannya. Setelah dilakukan wawancara dengan guru kelasnya, terungkap bahwa anak-anak yang menyendiri memiliki riwayat kesepian karena kesulitan mendapatkan teman dan mereka kebanyakan seorang pecandu game. Kegiatan anakanak tersebut dirumah hanya bermain gadget karena mereka tidak memiliki teman bermain. 
Adanya peraturan di sekolah yang melarang siswa nya membawa gadget ke sekolah, membuat anak-anak yang terindikasi kecanduan gadget ini merasa kesulitan bermain dengan teman sekelasnya sehingga anak-anak ini hanya duduk diam di kelas ketika jam istirahat tiba.

Dari hasil wawancara dengan guru Bk, terdapat beberapa kendala dalam pelaksanaan kegiatan layanan BK di sekolah tersebut, diantarany (1) terdapat beberapa siswa yang kesulitan dalam penyesuaian lingkungan baru, (2) pelaksanaan kegiatan layanan BK terkendala masalah sarana dan prasarana, (3) kurangnya dukungan personil sekolah dalam pelaksanaan layanan BK, (4) media yang terbatas dan kurang sesuai dengan kondisi siswa.

Siswa yang belum mengenal permainan tradisional Balbudih, diperlihatkan video tentang permainan Balbudih. Selanjutnya siswa diminta untuk mempraktekkan permainan tradisional Balbudih dimana anggota kelompok dipilih oleh guru BK. Melalui permainan tradisional Balbudih yang dimainkan langsung oleh siswa dan dibimbing oleh Guru BK yang berkolaborasi dengan guru PJOK, terlihat secara jelas siswa yang pada awal permainan masih canggung satu sama lain akhirnya menjadi kompak saling bekerja sama untuk memenangkan tim nya dalam permainan trandisional Balbudih tersebut. Siswa saling berinteraksi satu sama lain dan tetap focus pada satu tujuan permainan.

Validasi ahli dilakukan melalui penilaian ahli dalam bidang BK sebagai ahli 1 dan media pendidikan sebagai ahli 2. Uji ahli dilakukan melalui uji akseptabilitas yang mencakup; kegunaan, kelayakan, ketepatan serta relevansi buku panduan dan video permainan tradisional Balbudih.

Table 1 Hasil Penilaian Uji Kegunaan (Utility) Panduan Permainan Tradisional balbudih oleh ahli 1 dan 2

\begin{tabular}{|c|c|c|c|c|}
\hline \multirow[t]{2}{*}{ Pernyataan } & \multicolumn{2}{|c|}{ Tingkat Kegunaan } & \multirow[t]{2}{*}{ Jumlah } & \multirow[t]{2}{*}{$\%$} \\
\hline & Ahli 1 & Ahli 2 & & \\
\hline 1 & 3 & 4 & 7 & 87,5 \\
\hline 2 & 3 & 4 & 7 & 87,5 \\
\hline 3 & 3 & 4 & 7 & 87,5 \\
\hline 4 & 4 & 4 & 8 & 100 \\
\hline 5 & 3 & 4 & 7 & 87,5 \\
\hline 6 & 3 & 4 & 7 & 87,5 \\
\hline Jumlah & 19 & 24 & 50 & 89,28 \\
\hline$\%$ & 79,17 & 100 & & \\
\hline
\end{tabular}

Tabel tersebut di atas menunjukkan bahwa dari hasil uji kegunaan (utility) terdapat 6 (enam) pernyataan akseptabilitas untuk menilai kegunaan video dan buku panduan permainan tradisional Balbudih sebagai media bimbingan konseling. Penilaian yang dilakukan oleh ahli pertama yaitu nilai total 19 (79,17\%), kemudian ahli kedua memberi nilai total 24 (100\%). Rata-rata nilai dari hasil uji kegunaan diperoleh nilai sebesar 89,28\% yang menunjukkan data tersebut 
menggambarkan tingkat kegunaan dari panduan dan video permainan tradisional Balbudih yang besar. Khususnya kegunaan dalam upaya meningkatkan keterampilan sosial siswa.

Table 2 Hasil Penilaian Uji Kelayakan (feasibility) Panduan Permainan Tradisional balbudih oleh ahli 1 dan 2

\begin{tabular}{ccccc}
\hline \multirow{2}{*}{ Pernyataan } & \multicolumn{2}{c}{ Tingkat Kelayakan } & \multirow{2}{*}{ Jumlah } & \multirow{2}{*}{$\%$} \\
\cline { 2 - 4 } & Ahli $\mathbf{1}$ & Ahli $\mathbf{2}$ & 6 & 75 \\
\hline 1 & 3 & 3 & 6 & 62.5 \\
\hline 2 & 3 & 3 & 5 & 100 \\
\hline 3 & 3 & 2 & 8 & 62.5 \\
\hline 4 & 4 & 3 & 5 & 62.5 \\
\hline 6 & 2 & 3 & 5 & $\mathbf{7 2 . 9 2}$ \\
\hline Jumlah & 2 & $\mathbf{1 8}$ & $\mathbf{3 5}$ & \\
\hline$\%$ & $\mathbf{1 7}$ & $\mathbf{7 5}$ & & \\
\hline
\end{tabular}

Tabel 2 tersebut, menunjukkan bahwa dari hasil uji kelayakan (feasibility oleh kedua ahli tersebut yang terdiri atas 6 item pernyataan akseptabilitas untuk menilai kelayakan video dan buku panduan permainan tradisional Balbudih. Penilaian dari ahli pertama memiliki nilai yakni nilai total $17(70.83 \%)$, kemudian ahli kedua memberi nilai total 18 (75\%). Dari nilai tersebut, maka rata-rata nilai dari hasil uji kelayakan diperoleh nilai sebesar $35(72.92 \%)$ sehingga dari data ini diketahui bahwa video dan buku panduan permainan tradisional Balbudih memiliki tingkat kelayakan (feasibility) yang besar bagi pembimbing maupun siswa di sekolah.

Table 3 Hasil Penilaian Uji Ketepatan (Accuracy) Panduan Permainan Tradisional balbudih oleh ahli 1 dan 2

\begin{tabular}{ccccc}
\hline \multirow{2}{*}{ Pernyatan } & \multicolumn{2}{c}{ Tingkat Ketepatan } & \multirow{2}{*}{ Jumlah } & \multirow{2}{*}{ Ahli 2 } \\
\cline { 2 - 3 } & Ahli $\mathbf{1}$ & 3 & 6 & 75 \\
\hline 1 & 3 & 3 & 6 & 75 \\
\hline 2 & 3 & 4 & 7 & 87.5 \\
\hline 3 & 3 & 4 & 7 & 75 \\
\hline 4 & 3 & 3 & 6 & 75 \\
\hline 5 & 3 & 3 & 6 & $\mathbf{7 9 . 1 7}$ \\
\hline Jumlah & 3 & $\mathbf{2 0}$ & $\mathbf{3 8}$ & \\
\hline$\%$ & $\mathbf{1 8}$ & $\mathbf{8 3 . 3 3}$ & & \\
\hline
\end{tabular}

Tabel 3 tersebut menunjukkan bahwa hasil uji ketepatan (accuracy) oleh kedua ahli tentang pernyataan akseptabilitas untuk menilai ketepatan video dan buku panduan permainan tradisional Balbudih sebanyak 6 item pernyataan. Penilaian yang dilakukan oleh ahli pertama yaitu sebesar 18 (75\%), kemudian ahli kedua memberi nilai sebesar 20 (83,33\%). Sehingga rata-rata nilai dari hasil uji ketepatan diperoleh sebesar 38 (79,16\%), sehingga dari data tersebut dapat diketahui bahwa video dan buku panduan permainan tradisional Balbudih memiliki tingkat ketepatan (accuracy) yang besar. 
Table 4 Hasil Penilaian Uji Relevansi Panduan Permainan Tradisional balbudih oleh ahli 1 dan 2

\begin{tabular}{cccccc}
\hline \multirow{2}{*}{ Pernyatan } & \multicolumn{2}{c}{ Tingkat Relevansi } & \multirow{2}{*}{ Jumlah } & \multirow{2}{*}{$\%$} \\
\cline { 2 - 4 } & Ahli 1 & Ahli 2 & & \\
\hline 1 & 3 & 3 & 6 & 75 \\
\hline 2 & 3 & 3 & 5 & 62.5 \\
\hline 3 & 3 & 4 & 8 & 100 \\
\hline 4 & 4 & $\mathbf{1 2}$ & $\mathbf{2 5}$ & $\mathbf{7 8 . 1 2 5}$ \\
\hline Jumlah & $\mathbf{1 3}$ & $\mathbf{7 5}$ & & \\
\hline
\end{tabular}

Dari Tabel tersebut diketahui bahwa dari terdapat 4 item pernyataan yang dilakukan uji relevansi oleh kedua ahli untuk menilai relevansi video dan buku panduan permainan tradisional Balbudih. Penilaian oleh ahli pertama memiliki nilai total sebesar 13 (81.25\%), sedangkan ahli kedua memberi nilai dengan total 12 (75\%). Rata-rata nilai hasil uji relevansi dari kedua ahli diperoleh nilai sebesar 25 (78.125\%), sehingga dari data ini dapat dinyatakan bahwa video dan buku panduan permainan tradisional Balbudih memiliki tingkat relevansi yang besar untuk digunakan bagi guru pembimbing maupun siswa di sekolah.

Berdasarkan hasil penilaian akseptabilitas mengenai kegunaan, kelayakan, ketepatan, dan relevansi diatas, diketahui bahwa penilaian video dan buku panduan permainan tradisional Balbudih yang diberikan oleh dua ahli menyimpulkan bahwa panduan ini telah layak untuk digunakan di sekolah menengah.

Revisi I dilakukan berdasarkan hasil uji ahli. Berdasarkan hasil uji ahli tersebut, secara keseluruhan para ahli menyatakan bahwa buku panduan dan video permainan tradisional Balbudih yang digunakan sebagai media dalam layanan bimbingan dan konseling untuk upaya peningkatan keterampilan sosial siswa sudah dalam kategori yang baik dan dapat diterapkan di sekolah. Setelah proses tahap uji ahli dilakakukan, maka peneliti melanjutkan ke tahap selanjutnya yaitu uji coba kelompok kecil.

Uji kelompok kecil merupakan uji kelompok yang digunakan untuk mengetahui tingkat kelayakan, keberterimaan, dan keterpakaian sebuah produk panduan yang dikembangkan dan halhal apa saja yang perlu direvisi sebelum menentukan produk akhir dari sebuah penelitian pengembangan. Dalam uji kelompok kecil ini, digunakan 10 orang siswa siswa menengah yang terdiri dari kelas VII.A dan VII.B. Turut pula melibatkan 2 orang guru BK dan 1 orang guru PJOK di SMP Negeri 1 Saronggi. Pada kegiatan ini, siswa dan guru di berikan angket tanggapan mengenai penduan permainan tradisional Balbudih sebagai media bimbingan konseling dalam meningkatkan keterampilan sosial siswa. Dari angket tanggapan untuk siswa berisi 10 item pernyataan. Hasil dari angket tanggapam yang diisi oleh 10 siswa diperoleh total nilai sebesar $86,25 \%$, sehingga dari data ini peneliti dapat menarik kesimpulan bahwa panduan permainan tradisional Balbudih memiliki tingkat kelayakan dan keberterimaan yang besar bagi siswa di SMP 
Negeri 1 Saronggi. Sementara berdasarkan hasil dari angket tanggapan oleh 2 guru BK dan 1 guru PJOK diperoleh total nilai sebesar 67 atau 83,75\% sehingga dari data ini diketahui bahwa panduan permainan tradisional Balbudih memiliki tingkat kelayakan dan keberterimaan yang besar bagi guru BK di SMP Negeri 1 Saronggi.

Selanjutnya dilakukan revisi tahap 2. Revisi kedua dilakukan berdasarkan data dari hasil uji coba kelompok kecil. Uji coba kelompok kecil itu dilakukan sebanyak lima tahap kegiatan dalam pelaksanaan Panduan Permainan Tradisional Balbudih. Kelima tahap kegiatan dari panduan Permainan Tradisional Balbudih tersebut di lakukan oleh peneliti. Adapun proses pelaksanaan lima kegiatan secara umum yang dilakukan meliputi persiapan, penyampaian, pelatihan dan penilaian atau evaluasi. Hasil uji coba kelompok kecil yang masuk nantinya dijadikan sebagai bahan analisa dalam melakukan revisi kedua pada panduan Permainan Tradisional Balbudih.

\section{DISKUSI}

Permainan tradisional lazimnya dimainkan oleh lebih dari satu anak dalams ebuah tim sehingga didalam proses bermain tersebut, anak dituntut untuk melakukan interaksi dengan teman satu tim ataupun dengan lawan mainnya, selain itu didalam permainan tradisional juga terdapat beberapa aturan main yang harus ditaati oleh setiap pemain, yang melatih mereka untuk lebih disiplin. Eliasa (2011) mengungkapkan bahwa bermain dapat mengajarkan anak untuk mengurangi sifat egoisnya karena dalam permainan tradisional dituntut untuk bersaing dengan jujur, sportif, memahami hak dan kewajiban dalam permainan, serta sebagai sarana belajar komunikasi dan berorganisasi. Hasil penelitian yang dilakukan oleh Kurniati (2006) menunjukkan bahwa permainan tradisional dapat menstimulasi anak dalam mengembangkan kemampuan kerja sama, membantu anak dalam menyesuaikan diri, saling berinteraksi secara positif, dapat mengontrol dirinya, mengembangkan sikap empati terhadap teman, menaati aturan, serta menghargai orang lain

Berdasarkan hasil assasment dan analisis kebutuhan, diperoleh sebuah kebutuhan akan sebuah media yang digunakan untuk mengembangkan keterampilan kerjasama siswa melalui kegiatan yang menantang bagi siswa. Berdasarkan hasil diatas, maka permainan tradisional Balbudih dipilih sebagai media dalam membantu siswa meningkatkan keterampilan sosialnya. Permainan tradisional Balbudih ini sudah jarang dimainkan oleh warga di Sumenep Madura, oleh karena itu penggunaan permainan tradisional ini bisa digunakan sebagai media menjaga budaya daerah Sumenep. 
Bimbingan dan konseling di sekolah merupakan salah satu upaya yang dapat digunakan dalam menangani masalah siswa. Kesuksesan pemberian layanan bimbingan dan konseling di sekolah salah satunya dapat dipengaruhi oleh metode yang digunakan oleh guru BK, penggunaan media yang tepat dapat memberikan layanan bimbingan dan konseling yang menarik dan menyenangkan serta efektif serta dukungan dari seluruh steakholder sekolah.

Mengacu pada Panduan Operasional Penyelenggaraan Bimbingan dan Konseling Sekolah Menengah Pertama tahun 2016 dijelaskan bahwa terdapat aspek perkembangan kesadaran tanggung jawab sosial yang harus dicapai oleh konseli yaitu berinteraksi dengan orang lain atas dasar nilai-nilai persahabatan dan keharmonisan hidup, namun kondisi siswa di sekolah menunjukkan beberapa hal yang bertentangan yaitu bahwa siswa mengalami kesulitan dalam beradaptasi dan menyesuaikan diri dengan teman-temannya, komunikasi dan pertemanan yang kurang baik antara satu siswa dengan siswa yang lain, kurangnya empati dan rasa saling menghargai satu dengan yang lain, siswa cenderung asik dengan dirinya sendiri terutama saat bermain game online, siswa yang cenderung lebih asik berinteraksi dengan dunia maya daripada berinteraksi langsung dengan teman-teman dilingkungannya, kurangnya interaksi dan dinamika kelompok yang baik saat siswa berada dalam satu kelompok belajar, kurangnya kedisiplinan maupun kepercayaan diri siswa yang berdampak pada interaksi sosialnya. Melihat keadaan tersebut diperlukan adanya metode layanan bimbingan dan konseling yang efektif dan menyenangkan untuk siswa, yang melibatkan siswa dalam interaksi dan dinamika kelompok yang bertujuan dalam meningkatkan keterampilan sosial siswa di sekolah

Berdasarkan hasil penelitian dan pembahasan serta tahap pengembangan panduan dapat ditarik kesimpulan bahwa: (1) penelitian pengembangan ini menghasilkan mengembangkan panduan bimbingan ketrampilan kerjasama berbasis Permainan Tradisional Balbudih untuk siswa SMP telah memenuhi kriteria akseptabilitas yang dilakukan melalui uji ahli dan uji calon pengguna. (2) Menghasilkan panduan bimbingan berbasis permainan tradisional Balbudih yang efektif untuk meningkatkan keterampilan kerjasama siswa SMP.

Sehubungan kesimpulan penelitian di atas, maka diajukan saran-saran sebagai berikut: (1) perlu dilakukan penelitian yang lebih lanjut mengenai tingkat efektivitas panduan permainan tradisional Balbudih sebagai media yang digunakan dalam meningkatkan keterampilan sosial siswa berbasis permainan tradisional, (2) perlu adanya penelitian lebih lanjut mengenai kebutuhankebutuhan siswa di sekolah lain mengenai keterampilan sosial siswa, sehingga materi-materi lain dapat mengembangkan sebuah produk media yang menggunakan kearifan local budaya setempat. 


\section{REFERENSI}

Akay, S., \& Bratton, S. (2017). The effects of Adlerian play therapy on maladaptive perfectionism and anxiety in children: A single case design. International Journal of Play Therapy, 26(2), 96.

Andriani, D. G., Kusmayadi, T. A., \& Mardiyana, M. (2013). Eksperimentasi model pembelajaran kooperatif tipe jigsaw ii dan think pair share ditinjau dari kecerdasan emosional siswa smp se-kota kediri tahun pelajaran 2012/2013. Jurnal Pembelajaran Matematika, 1(7).

Ariani, C. (1998). Pembinaan Nilai Budaya Melalui Permainan rakyat Daerah Istimewa Yogyakarta. Yogyakarta: Dekdikbud, Dirjen Kebudayaan, Direktorat Sejarah dan Nilai Tradisional.

Bekoff, M. (2011). Social Play Behaviour: Cooperation, Fairness, Trust ang the Evolution of Morality. Journal of Consciousness Studies, 8(2), 81-90.

Bishop, J.C \& Curtis, M. 2005. Permainan Anak Jaman Sekarang. Editor: Youlta Hadiwati. Jakarta: PT. Grasindo.

Borg \& Gall. 2003. Education Research An Introduction. New York: Longman.

Goleman, Daniel. 2010. Social Intelligence - The New Science Of Human Relationship. Jakarta: PT Gramedia.

Hurlock, E. B. 1990. Developmental Psychology: A lifespain Approach. Boston: Mc Graw: Hill.

Iswinarti. (_ ). Nilai-nilai terapiutik permainan tradisional Engklek Pada anak usia sekolah dasar. Jurnal fakultas Psikologi UMM.

Kartini Kartono. (2007). Psikologi Anak. Bandung: Mandar Maju.

Mayke S. Tedjasaputra, 2005. Bermain, Mainan dan Permainan Untuk Pendidikan Usia Dini. Jakarta: Grasindo.

Prayitno dan Amti, E. (2013). Dasar-Dasar Bimbingan \& Konseling. Jakarta: PT. Rineka Cipta

Rose Chepyator-Thomson, Jepkorir Traditional Games of Keijo Children: A Comparison of Pre-and Post-Independent Periods in Kenya. Interchange, Vol. 21, No. 2 (Summer, 1990), 15-25.

Salter, Kerri; dkk. 2016. The Effects of Child - Centered Play Therapy (CCPT) on the Social and Emotional Growth of Young Australian Children with Autism. International Journal Of Play Therapy, 2016, Vol. 25, No. 2 page 78 - 90.

Setyawan, Abbas. (2013). Preservation of Gobak Sodor Traditional Games Using Augmented Reality Computer Game Simulation. 2013 International Conference of Information and Communication Technology (ICoICT). 978-1-4673-4992-5/13/\$31.00 C2013 IEEE.

SHoaakazemi, Mehrangiz. 2012. The effect of group play therapy on reduction of separation anxiety disorder in primitive school children. Procedia - Social and Behavioral Sciences 69 (2012) 95 - 103.

Siti Irene Astuti Dwiningrum, dkk. (2012). Ilmu Sosial \& Budaya Dasar. Yogyakarta: UNY Press.

Siti Munawaroh. (2011). Permainan Anak Tradisional Sebuab Model Pendidikan Dalam Budaya. Yogyakarta: Depdikbud. Direktorat Sejarah dan Nilai Tradisional.

Slamet Suyanto. (2005). Dasar-Dasar Pendidikan Anak Usia Dini. Yogyakarta: Hikayat Publishing.

Sujarno. (2010). Nilai-nilai Yang Terkandung Dalam Permainan Tradisional Di Kabupaten Cilacap. Jurnal Partrawidya (Vol.11, No. 1). Hlm. 145-175.

Sukirman Dharmamulya. (2008). Permainan Tradisional Jawa. Yogyakarta: Kepel Press.

Susanto, A. (2011). Perkembangan Anak Usia Dini. Jakarta: Prenada Media Group. 
Theodora. E. 2011. Meningkatkan Kemampuan kerjasama belajar biologi melalui penerapan strategi inkuiri terbimbing pada siswa kelas VII SMP Negeri VII Kota Samarinda tahun pelajaran 2010/2011. Jurnal bioedukasi volume 2, nomor 1, mei 2011.

Y. Hatta, Raden Trimulia. 2018. Kecanduan Smartphone, kondisi 2 remaja di RS Jiwa Bandung. Digital: news.liputan6.com.

2018. Anak digital: Membesarkan Anak Generasi Digital. Digital: Metrotvnews.com

Yuzarion, Y., Agustiana, A. K., Alfaiz, A., Yandri, H., Musdizal, M., \& Aulia, R. (2020). Learning achievement reviewed from self regulated learning, future orientation, and parental support. COUNS-EDU: The International Journal of Counseling and Education, 5(2), 71-80. 